\title{
Variation of a benthic heterotrophic bacteria community with different respiratory metabolisms in Coyuca de Benítez coastal lagoon (Guerrero, Mexico)
}

\author{
María Jesús Ferrara-Guerrero, María Elena Castellanos-Páez \& Gabriela Garza-Mouriño \\ Universidad Autónoma Metropolitana-Xochimilco. Departamento La persona y su Ambiente. Calzada del Hueso \\ 1100, Col. Villa Quietud, 04960 México D.F., México. Fax.+5255-54-83-74-69; fgmd6735@correo.xoc.uam.mx
}

Received 06-IX-2003. C Corrected 24-IV-2006. Accepted 15-XII-2006.

\begin{abstract}
The fluctuations of the number, biomass and composition of the heterotrophic community were studied daily for two days, according to depth, $\mathrm{pH}, \mathrm{Eh}, \mathrm{O}_{2}$ and organic carbon concentration within a zone of the canal between the Coyuca de Benítez lagoon (Guerrero, Mexico) and the coastal waters. At the three moments of the day studied ( $6 \mathrm{am}, 2 \mathrm{pm}$ and $10 \mathrm{pm})$, the oxygen concentrations in the overlying water and in the superficial sediment layer were near air-saturation in the diurnal samplings $(582 \mu \mathrm{M}$ at 6 am and $665 \mu \mathrm{M}$ at $2 \mathrm{pm})$, and sub-satured during the night $(158 \mu \mathrm{M})$. In the sediments, the models of vertical distribution of Eh and organic carbon distributions were very irregular due to the bio-perturbation of the benthic, meio- and macrofauna, whose activity allows the superficial organic carbon to migrate towards sediment deeper layers. Vertical distribution of the different viable bacteria populations seems to be related to the hydrodynamic patterns of the communicating canal and sediments heterogeneity. In the sediment column, the heterotrophic bacteria total number varied from 6.8 to $20.3 \times 108$ cells $\mathrm{cm}^{-3}$. The highest heterotrophic bacterial biomass values were encountered during the diurnal samplings $\left(39.2 \mu \mathrm{gC} .1^{-1}\right.$ at $6 \mathrm{am}$ and $34.4 \mu \mathrm{gC} .1^{-1}$ at $\left.2 \mathrm{pm}\right)$ and the lowest during the night $\left(9.7 \mu \mathrm{gC} .1^{-1}\right)$. The fluctuations of viable heterotrophic bacteria populations with different respiratory metabolisms (aerobic, microaerophilic and anaerobic) can be explained by the existence of suboxic microniches that appear when particles of sediment are resuspended due to the water circulation and the benthic infauna excavating activity, that allows the supernatant water oxygen to penetrate through its galleries towards deeper sediment zones. The statistical analysis (Multiple lineal regression model $r^{2} \geq 0.5$ ) showed that the on the whole, the hydrological parameters are not influence over the bacterial number and bacterial biomass distribution $\left(r^{2} \leq 0.5\right)$, Nevertheless, the variations of the heterotrophic bacteria community observed in the two days sampling, seem to be governed (with F-values of 0.6 to 0.9 ) by the irregular flows of bio-available organic material and the sediment porosity. Rev. Biol. Trop. 55 (1): 157-169. Epub 2007 March. 31.
\end{abstract}

Key words: coastal lagoon, oxygen, sediments, heterotrophic, microaerophilic, aerobic, anaerobic bacteria.

Coastal lagoons, under direct influence of wind regimes and water movements, may show temporary periods of oxygen saturation or anoxia. In such environments, the nutrients and oxygen availability are function of the ebb and flow of the lagoon water and the daily variation of the activity and structure of the benthic and planktonic microbial populations (Hicks 1992).

The contribution of bacteria to the total planktonic biomass of most aquatic communities is highly significant (Watson et al. 1977, Holligan et al. 1984, Fuhrman et al. 1989) because they play a major role in pelagic and benthic food networks and biogeochemical cycles (Azam et al. 1983, Cho and Azam 1990, Sanders et al. 1992). Seasonal changes in microbial activity in a temperate environment would be expected to be strongly affected by physical parameters, most notably temperature, which have a directly effect in changes in the activity, species composition and density of the 
bacteria and bacterivore assemblages (Caron et al. 1986, Pomeroy et al. 1991). Nevertheless, short-term changes may be responsive to biological features of the community as the rapid oscillations in the abundance of bacteria and their consumers due to the predator-prey relationship within the plankton. Transient storm events also may significantly affect microbial processes on short time scales. (Wikner et al. 1990, Marrasé et al. 1992).

The redox potential (Eh) is one the most important parameters characterizing the surface sediments, since it reflects the intensity of organic matter degradation and bacterial activity and indicates changes in the oxidation of organic material. This results from the fact that during the degradation of organic matter occurring successive redox reactions (MaksymowskaBrossard and Piekarek-Jankowska 2001). The redox potential measurements as an indicator of the sediment oxidation level have shown the existence of a two-layer system: one aerobic, relatively thin superficial layer over another deep and anaerobic layer. Nevertheless, this is not so clear owing to the fact that the sediment surface is very heterogeneous, and there are frequently reduced microniches in aerobic zones (Morris 1984, Marty et al. 1989).

The bacterioplankton assemblage is numerically dominated by heterotrophic bacteria, which lives via oxidation of organic substrates. In oxygenated waters, microbes grow by catabolizing organic molecules via aerobic respiration; under conditions of low oxygen availability, either in water mass or in microsites of intense microbial activity, nitrate and sulfate may be used as alternate terminal electron acceptors via anaerobic respiration. Fermentation may become important when oxygen is low or completely absent. Because of the high energy yield of aerobic respiration, most organic compounds can eventually be degraded by heterotrophic bacteria growing in oxygenated environments. Anaerobic processes are not usually considered to be significance in pelagic microbial food webs. However, anoxic conditions can occur inside organic particles such as fecal pellets (Alldredge and
Cohen 1987). Also, increased eutrophication of coastal regions has led to frequent formation of suboxic/anoxic water masses in which anaerobic metabolism replaces aerobic metabolism in microbial communities (Sherr and Sherr 2000). Most studies realized on the bacterial distribution according to the concentration of dissolved oxygen in aquatic environments were done on the water column samples, but little is known about these processes on sediments owing to the technical difficulties that this implies (Jørgensen and Revsbech 1985, Daumas 1989, Ferrara-Guerrero and Bianchi 1990, Cammen 1991, Rasmussen and Jørgensen 1992, Roden and Tuttle 1992).

No studies about the bacterial trophic state in the Coyuca de Benitez lagoon (Guerrero, Mexico) are available; therefore the present work was done with the main purpose to study of in situ spatial fluctuations of the heterotrophic bacteriobenthos, in a short scale of time in relation to the physical and chemical changes in the environment.

\section{MATERIAL AND METHODS}

Study area: The Coyuca de Benítez coastal lagoon is located northwest from Acapulco, Guerrero, Mexico, between $16^{\circ} 54^{\prime}$ and $16^{\circ} 58^{\prime}$ $\mathrm{N}$, and $99^{\circ} 57^{\prime}$ and $100^{\circ} 10^{\prime} \mathrm{W}$ (Fig. 1). The lagoon is separated from the Pacific Ocean by a sandbank of approximately $500 \mathrm{~m}$, near of the communicating canal, and has an average depth of $2.50 \mathrm{~m}$, with a maximum depth of $5 \mathrm{~m}$ (Contreras 1985).

The climate is tropical sub-humid, with annual average temperatures from 24 to $27^{\circ} \mathrm{C}$; the hydrological levels depend directly on the rain since all the rivers flowing into it have a rainy regime, except for the Coyuca River which flows all the year (Monreal 1991).

The sampling station is located at the Southeast of the lagoon, near the mouth and in the mangrove forest strip. The samplings were done for two consecutive days in September 1998, when the mouth was open and the mean depth in the sampling site was $1.2 \mathrm{~m}$. 


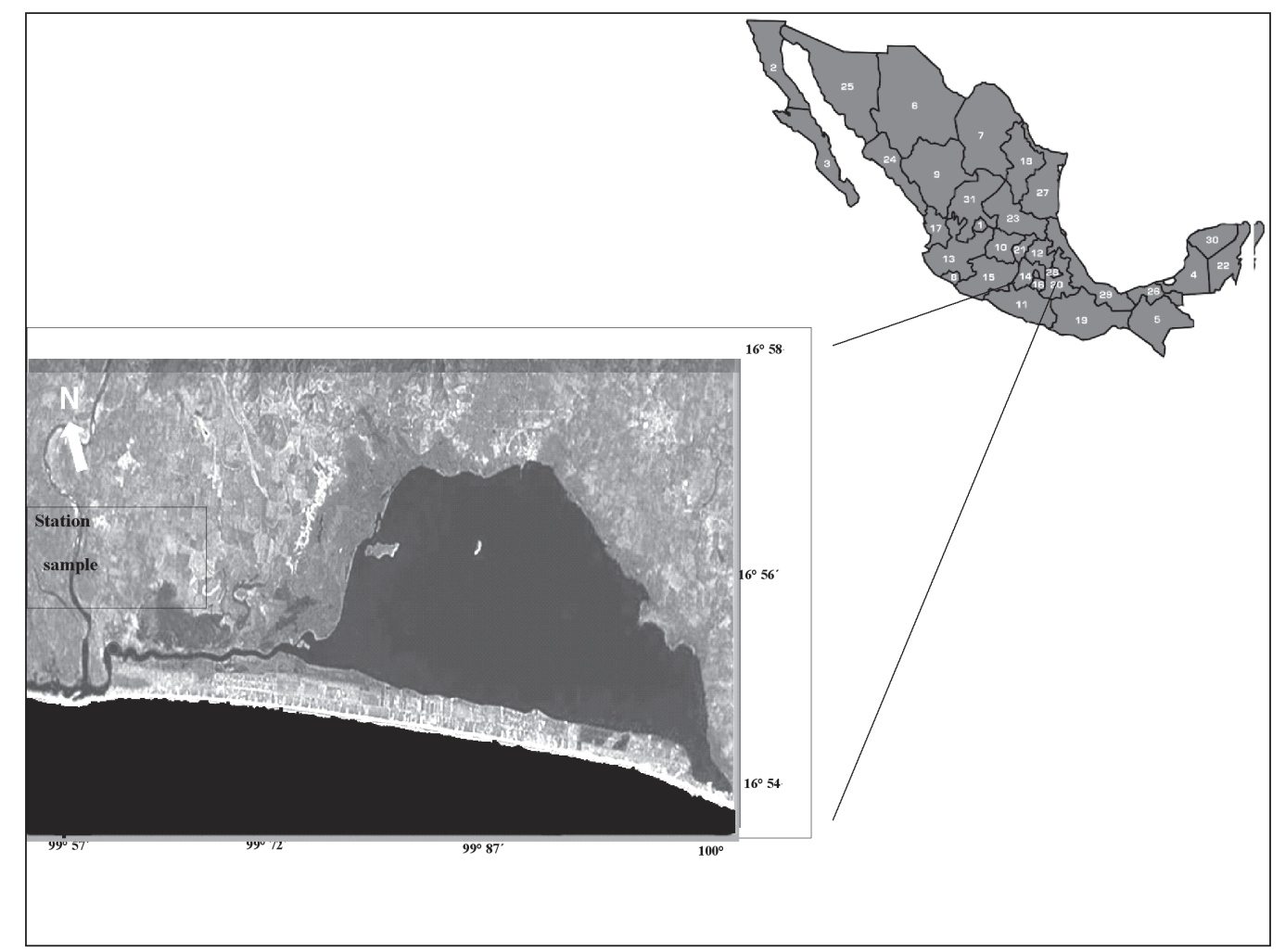

Fig. 1. Sampling site in Coyuca de Benitez lagoon (SE of Mexico).

Fig. 1. Sitios de muestreo en la laguna de Coyuca de Benitez (SE de México).

The sediment samples were taken at different moments of the day: in the morning (6 am), in the afternoon $(2 \mathrm{pm})$ and at night $(10 \mathrm{pm})$.

Sediment sampling and characteristics: The samples of the bottom water and upper layer sediments were collected twice with Plexiglas corers $(3 \times 13 \mathrm{~cm})$, perforated every $5 \mathrm{~mm}$ throughout. The introduction into the sediment was done carefully in order to get the sample with minimum perturbation. The 5 $\mathrm{cm}$-thick surface sediment layer was sliced into $5 \mathrm{~mm}$ segments for bacteriological, porosity and organic carbon analysis. The $\mathrm{pH}$ and the redox potential $(\mathrm{mV})$ into sediment core were measured immediately after sampling using a Orion $\mathrm{pH} / \mathrm{mV} / \mathrm{T}$ analyzer equipped with a $\mathrm{pH}$ mini-electrode of penetration (Ingold), with a $3 \mathrm{~mm}$ diameter and $30 \mathrm{~mm}$ of length, and a $\mathrm{Eh}$ mini-electrode with a platinum penetration-tip. The dissolved oxygen $(\mu \mathrm{M})$ on the overlaying water into the cores was measured in situ, with an air-calibrated polarographic electrode (Conductronic).

The sediment granulometry was determined by sequential sediment-sieving to evaluate the relative abundance (\%) of $<65 \mu \mathrm{m}$ size-fractions. The water content was determined as a percentage of water in relation to the total fresh sediment weight (Revsbech et al. 1980, Rasmussen and Jørgensen 1992), and the sediment organic carbon was measured as the percentage of weight loss by calcination ( 500 ${ }^{\circ} \mathrm{C}, 24 \mathrm{~h}$ ) from sediments dried (\% dry weight) at $105{ }^{\circ} \mathrm{C}$ during $24 \mathrm{~h}$ (Gallardo et al. 1987). Sediment water contents (porosity) were estimated by weight loss of wet sediment samples dried at $60{ }^{\circ} \mathrm{C}$. 
Bacterial enumerations: To demonstrate the presence of different metabolic bacterial groups, indirect Most Probable Number methods (MPN) were used. Viable heterotrophic aerobic bacteria were determined by using a modified liquid ZoBell medium (Oppenheimer and ZoBell 1952), and in rubber-stoppered vials with a controlled atmosphere $\left(90 \% \mathrm{~N}_{2} /\right.$ $10 \% \mathrm{CO}_{2}$ ) for anaerobes (Hungate 1969), and the microaerophilic in a SA500 semi-solid agar (Ferrara-Guerrero and Bianchi 1989, FerraraGuerrero et al. 1993) in a screw-capped tubes (15 x $140 \mathrm{~mm})$.

Samples for total bacterial enumeration were preserved with buffered formaldehyde at $2 \%$ final concentration. Preserved samples were prepared for counting as soon as possible; the volumes filtered are commonly used for samples with high microbial abundances (Hobbie et al. 1977, Porter and Feig 1980). In order to facilitate the separation of bacteria aggregates, $1 \mathrm{ml}$ of preserved sample was diluted into $9 \mathrm{ml}$ of $2 \mathrm{mM} \mathrm{Na}{ }_{4} \mathrm{P}_{2} \mathrm{O}_{7}$ (Albright et al. 1986), and then three times sonicated 20 min later on ice for $1 \mathrm{~min}$. (Utrasonic probe at low power), with $30 \mathrm{~s}$ intervals. Aliquots of an appropriate dilution were filtered $(1 \mathrm{ml})$ onto $0.2 \mu \mathrm{m}$ black polycarbonate filters and counted after 4'6-diamidino-2-phenylindole (DAPI) staining. The measurements of total bacterial population were done by direct counting method using an Olympus BIMAX 60 epifluorescence microscope, equipped with a Neofluor 100/1.25 N.A. (DapO) lens, a 100 W mercury lamp, and a PM50 photomicrography system.

The total bacterial biomass was measured by direct counting and the biovolume by using an image analyzer (Image Pro Plus 4.2). The specific biovolumes were measured according to cell dimensions (Bratbak 1985, van Wambeke 1988). The biomass was measured using a $0.27 \times 10^{-12} \mathrm{gC} \mathrm{m}^{-3}$ (carbon/biovolume) conversion factor (Torréton 1991).

Correlation analyses at the $95 \%$ confidence level were done by using the Statistica 4.0 program $(\mathrm{p} \leq 0.05)$ and a multiple lineal regression model (SAS 9.1.3 program $\mathrm{r}^{2} \geq 0.5$ ).

\section{RESULTS}

Granulometry and porosity: The sediments at the sampling site were of the sandyclay type; in the first $15 \mathrm{~mm}$ of depth, the proportion of particles under $63 \mu \mathrm{m}$ is $84.7 \pm 4.93 \%$ (Table 1), while in deeper layers (15 to $50 \mathrm{~mm}$ depth) the fraction $<63 \mu \mathrm{m}$ is higher $(28.67 \pm 4.5 \%)$ than in superficial layers $(15.2 \pm 4.9 \%)$. The porosity of the sediments also decreased $(\mathrm{p}<0.05)$ while the sediment depth increased (Fig. 2), and the lowest values were registered in the afternoon of the first day $(32.7 \pm 11.2 \%)$ due to an important water level decrease at the sampling station (30 $\mathrm{cm}$ depth).

Organic carbon: The organic carbon content (Fig. 3) showed erratic fluctuations at the three moments of the day studied. The highest particulate organic carbon concentration (5.8 $\%$ ) was encountered at the superficial layer of the sediment in the afternoon sampling. The

TABLE 1

Sediment samples characteristics, percent coarse $(63 \mu \mathrm{m})$ and small size fractions in $5 \mathrm{~mm}$ core sections

\section{CUADRO 1}

Características de las muestras de sedimento, porcentaje de las partículas grandes $(63 \mu \mathrm{m})$ y pequeñas en cada fracción de $5 \mathrm{~mm}$ del núcleo de sedimento

$\begin{array}{ccc}\begin{array}{c}\text { Depth } \\ (\mathrm{cm})\end{array} & \begin{array}{c}\text { Fraction }>63 \mu \mathrm{m} \\ (\%)\end{array} & \begin{array}{c}\text { Fraction }<63 \mu \mathrm{m} \\ (\%)\end{array} \\ 0.0-0.5 & 83.3 & 16.7 \\ 0.5-1.0 & 79.6 & 20.4 \\ 1.0-1.5 & 91.4 & 8.6 \\ 1.5-2.0 & 69.6 & 30.4 \\ 2.0-2.5 & 76.8 & 23.8 \\ 2.5-3.0 & 68.5 & 31.5 \\ 3.0-3.5 & 72.8 & 27.2 \\ 3.5-4.0 & 78.6 & 21.4 \\ 4.0-4.5 & 69.2 & 30.8 \\ 4.5-5.0 & 64.4 & 35.6\end{array}$




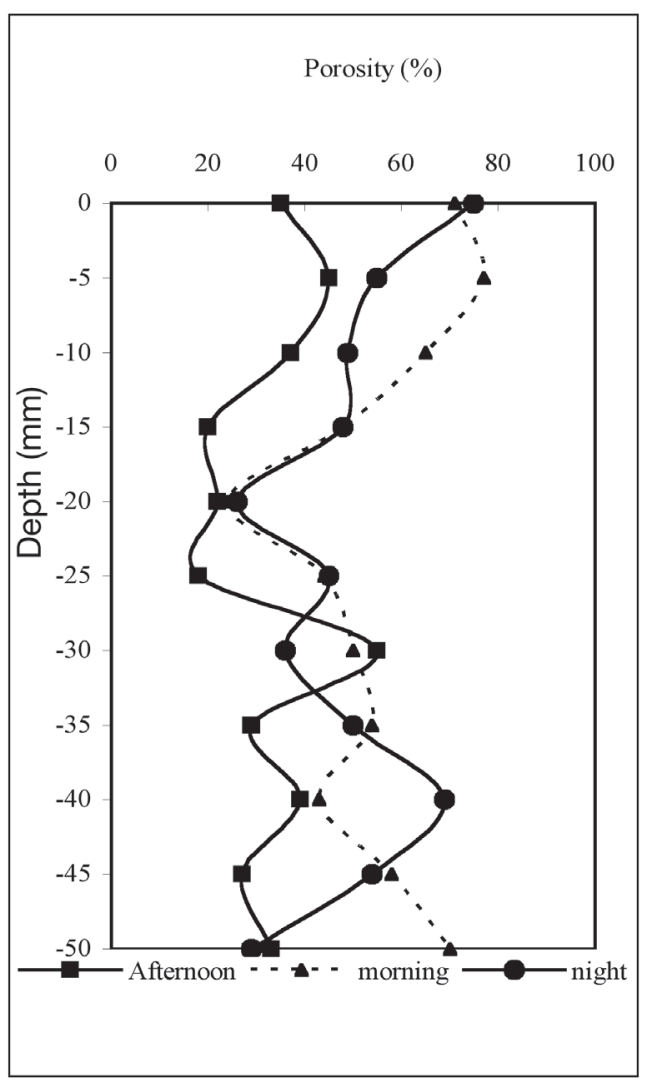

Fig. 2. Vertical variation in sediment porosity (\% pore water $\mathrm{v} / \mathrm{v}$ ) in $5 \mathrm{~mm}$ core sections, from morning, afternoon and night samplings.

Fig. 2. Variación vertical de la porosidad del sedimento ( $\%$ de agua intersticial $\mathrm{v} / \mathrm{v}$ ) en cada sección de $5 \mathrm{~mm}$ del núcleo, durante los muestreos de la mañana, tarde y noche.

organic carbon and porosity showed an inverse correlation at the three moments of the day studied $(\mathrm{p}<0.05)$.

pH, redox potential and oxygen concentration: The $\mathrm{pH}$ values showed no high variations in the whole samplings, neither in the bottom water $(8.15 \pm 0.11)$ nor in the interstitial water of sediments $(8.6 \pm 0.13)$.

The Eh profiles (Fig. 4) in the overlaying waters and sediments presented significant differences $(p<0.05)$ with depth for the three samplings done at different moments of the day ( $p>0.05)$. Based on Boyd's criteria (1995),

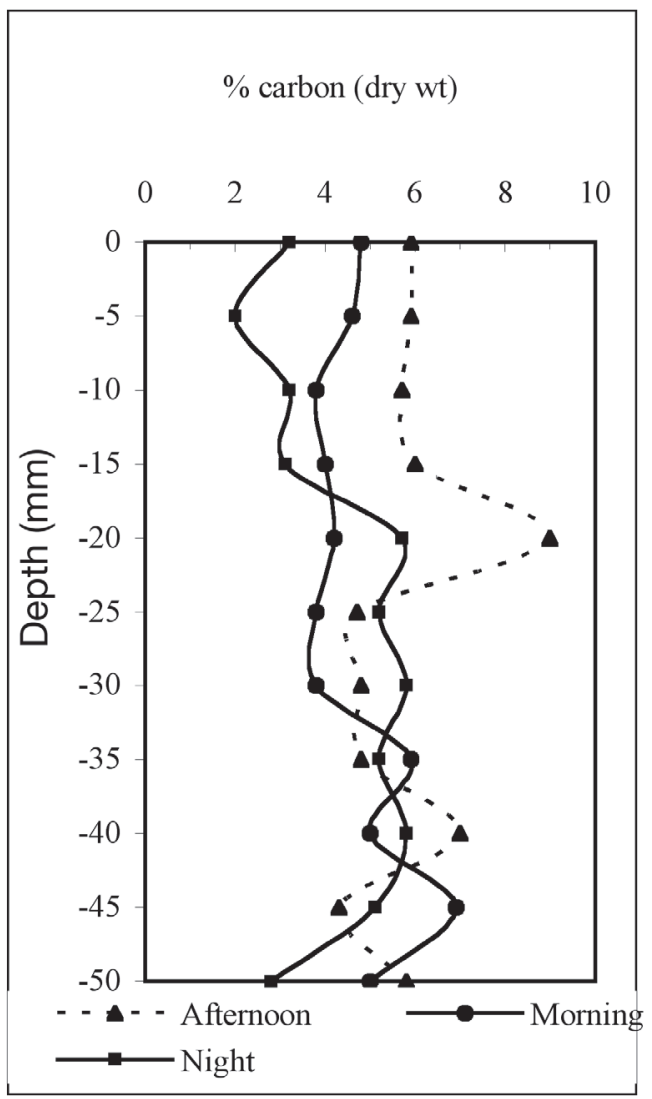

Fig. 3. Vertical variation in particulate organic carbon $(\%$ dry weight) in $5 \mathrm{~mm}$ core sections, from morning, afternoon and night samplings.

Fig. 3. Variación vertical del carbón orgánico particulado (\% peso seco) en cada sección de $5 \mathrm{~mm}$ del núcleo, durante los muestreos de la mañana, tarde y noche.

reducing conditions $(\mathrm{Eh}<100 \mathrm{mV}$ ) prevailed in the first $5 \mathrm{~mm}$ of sediments $(42.5 \pm 60 \mathrm{mV})$. In all the samplings, the redox potential in the deepest layers decreases rapidly to reach a maximum value of reduction $(-315 \pm 83 \mathrm{mV})$ at $50 \mathrm{~mm}$ depth. In the overlaying water, the Eh showed no significant differences $(p>0.05)$ in the samples taken in the three moments of the day studied $(146.9 \pm 13.3 \mathrm{mV})$; but it showed a direct relation with the sediment porosity $(\mathrm{p}<0.05)$.

According to oxygen concentration in the overlaying water, the highest concentrations were registered in the morning and the afternoon samplings $(582 \mu \mathrm{M}$ and $665 \mu \mathrm{M}$ 


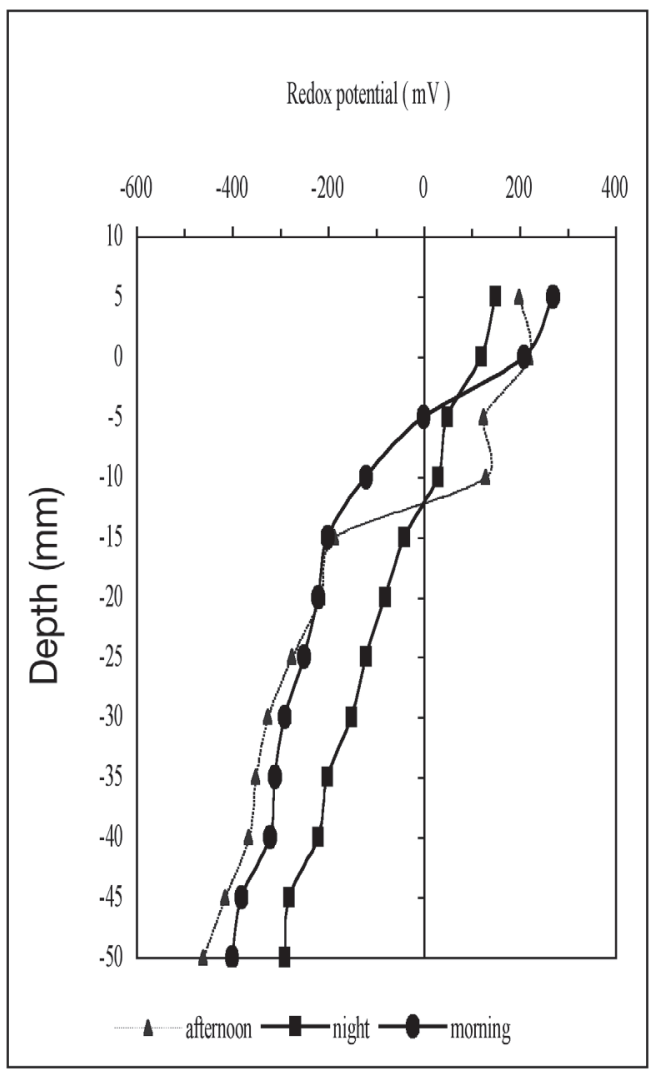

Fig. 4. Spatial variation of redox potential (Eh) in $5 \mathrm{~mm}$ core sections. Mean from six samplings into different light conditions. Morning, afternoon and night samples.

Fig. 4. Variación especial del potencial redox (Eh) en cada sección de $5 \mathrm{~mm}$ del núcleo. Media de seis muestreos dentro de diferentes condiciones de luz. Muestreos de mañana, tarde y noche.

respectively); this corresponds to the entry of seawater towards the lagoon. During the night, while the lagoon depth decreased, the oxygen concentration was $158 \mu \mathrm{M}$; this coincides with the low Eh values obtained.

Bacterial biomass: The heterotrophic bacteriobenthos number in the upper layer of the sediment was 100 to 1000 times higher than overlaying water bacterioplankton density (Fig. 5). In the sediment, the bacteria abundance ranged from 6.8 and $20.3 \times 10^{8}$ cells cm$~^{-3}$ and it decreases with the depth within the sediment core. The bacterial number and bacterial

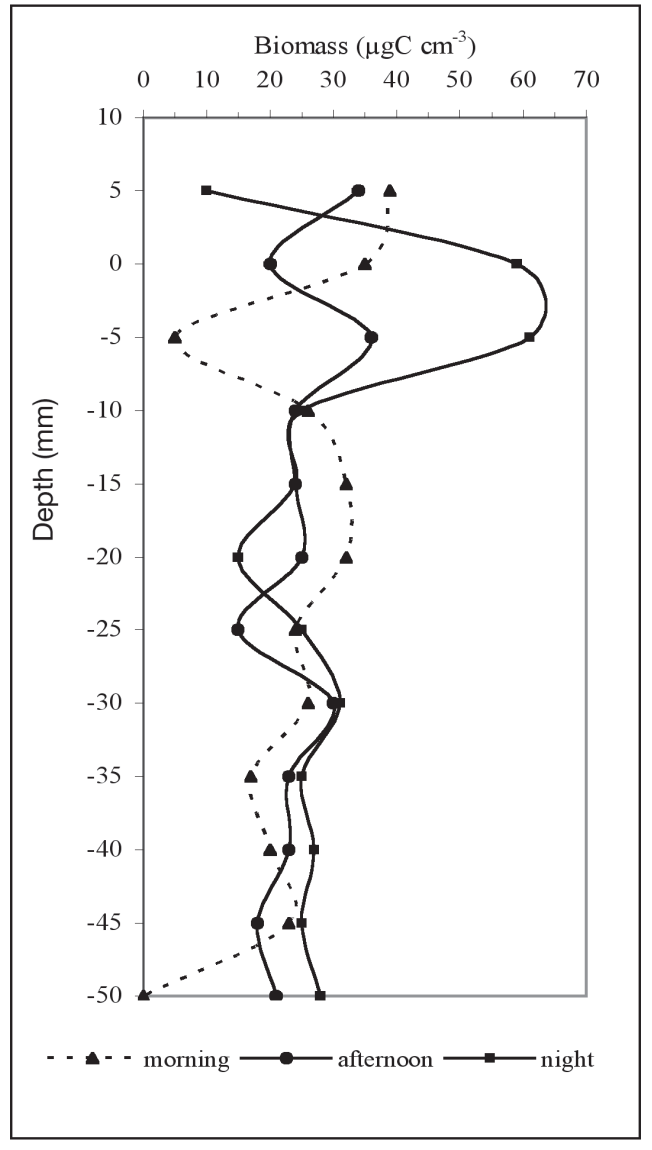

Fig. 5. Spatial variation of total bacteria biomass in bottom waters and $5 \mathrm{~mm}$ core sections into sediments, from morning, afternoon and night samples. In bottom water, total biomass is in $\mu \mathrm{g} \mathrm{C.1-1}$

Fig.5. Variación especial de la biomasa bacteriana total en agua de fondo y en cada sección de $5 \mathrm{~mm}$ de núcleo, durante los muestreos de la mañana, tarde y noche. En agua de fondo, la biomasa total está dada en $\mu \mathrm{g}$ C.1-1

biomass showed no clear relationship to sediment porosity and organic carbon concentration $\left(\mathrm{r}^{2} \geq 0.5\right)$, at the different moments of the day (F-values of 0.7).

Concerning the cellular volume measured, we observed no high differences between the overlaying water $\left(0.10 \pm 0.01 \mu \mathrm{m}^{3}\right)$, and the sediments interface $\left(0.11 \pm 0.05 \mu \mathrm{m}^{3}\right)$, with an average of $50 \leq n \geq 40$.

It exists direct relation between the biomass values and the moment of day sampling 
( $\mathrm{p} \geq 0.05$ ), so the maximum biomass average values in the overlaying water were found in the morning and afternoon samplings (39.2 \pm 1.7 and $33.4 \pm 4.8 \mu \mathrm{gC} .1^{-1}$ respectively), according to the entry of oceanic water into the lagoon. At night, during the stagnation period, the average values were much lower $(9.68 \pm 0.65 \mu \mathrm{gC}$. $\left.\mathrm{l}^{-1}\right)$. On the contrary, in the sediment upper layer (first $5 \mathrm{~mm}$ depth), we found the highest biomass values in the night sampling (58 1.4 $\left.\mu \mathrm{gC} .1^{-1}\right)$, but the values decrease suddenly in the next lower layers (Fig. 5). For all the samplings realized, the bacteriobenthos biomass distribution presents an irregular profile due to the heterogeneous nature of the sediment, and especially, due to the variable availability of bio-available substrates for the different bacterial groups.

On the other hand, in the morning sampling, we observed an increase in the number of filamentous cells in the bottom water $\left(4 \times 10^{5}\right.$ cells $\mathrm{ml}^{-1}$ ), with an important biovolume decrease $\left(0.94 \mu \mathrm{m}^{3}\right)$, while the maximum biovolumes were observed in the afternoon samplings (4.44 $\left.\mu \mathrm{m}^{3}\right)$, with a decrease of the abundance $(2 \mathrm{x}$ $10^{5}$ cells $\left.\mathrm{cm}^{-3}\right)$. In the upper layer sediments, the abundance of filamentous cells $\left(3.83 \times 10^{7}\right.$ $\left.\mathrm{cm}^{-3}\right)$ and the biovolume $\left(3.47 \mu \mathrm{m}^{3}\right)$, increased strongly at the night sampling. The biovolume variation coefficient for the filamentous cells during the day/night cycle in the different sediment layers was very high (121.8\%), while for the rod and vibrioid forms the variations were very low. The highest biovolume fluctuations were measured in the overlaying water and in the first five millimeters of the sediment; this matches with the zone of high fluctuations of dissolved oxygen concentration (oxic/anoxic interface), and particulate organic matter.

Viable bacterial community: In the overlaying water, we observed a high variation of the aerobic bacterial populations in all the samplings (Fig. 6). The maximum average values were encountered in the morning samplings $\left(9.5 \pm 0.71 \times 10^{5}\right.$ bacteria $\left.\mathrm{ml}^{-1}\right)$, while the minimum values were obtained at night $(3 \pm 0.42$ $\mathrm{x} 10^{2} \mathrm{ml}^{-1}$ ). In the sediment upper layer we observed an important increase of the number of aerobic bacteria in the afternoon samples $\left(8 \times 10^{5} \mathrm{~cm}^{-3}\right)$ and night samples $\left(1.1 \times 10^{6}\right.$ $\left.\mathrm{cm}^{-3}\right)$. Generally, the aerobic bacteria number decreased with increasing depth into the sediment core.

The diazotrophic microaerophilic bacteria were found in very low concentration in the bottom water ( 30 to 40 cells $\mathrm{ml}^{-1}$ ), and disappeared when the water was under oxygen supersaturation conditions (afternoon samplings $665 \mu \mathrm{M} \mathrm{O}_{2}$ ). Generally, the diazotrophic microaerophilic microflore in this sampling station only represented $0.03 \%$ of the total bacterial population in the bottom water.

In the sediment upper layers, this microbial population only represented 50 to 170 cells $\mathrm{cm}^{-3}$, and in the deep layers 13 to 140 cells $\mathrm{cm}^{-3}$ (Fig. 6).

Concerning the anaerobic bacterial populations, it was observed that they were always present, in the bottom water as well as in the sediments. In the overlaying water, it was obtained abundances between $9 \times 10^{1}$ and $2 \times$ $10^{3}$ cells $\mathrm{ml}^{-1}$, and the smallest were obtained in the afternoon samplings (oxygen supersaturation conditions, $665 \mu \mathrm{M})$.

In the sediments, the anaerobic bacterial population was higher than in the overlaying water; the abundance varied from $4.5 \times 10^{2}$ to $1.8 \times 10^{3}$ bacteria $\mathrm{cm}^{-3}$ in the first $5 \mathrm{~mm}$ of the sediment. The maximum average values were encountered between 5 and $20 \mathrm{~mm}$ depth; this matches with the maximum average values of particulate organic carbon.

Generally, in the sediments, the abundance of all the bacterial groups studied was higher than in the bottom water, especially the aerobic bacterial population. The vertical distribution of bacterial populations is not influenced by the Eh conditions of the interstitial water in the moment of sampling $\left(\mathrm{r}^{2} \geq 0.05\right)$.

\section{DISCUSSION}

The physical and chemical characteristics of the overlaying water and the superficial 


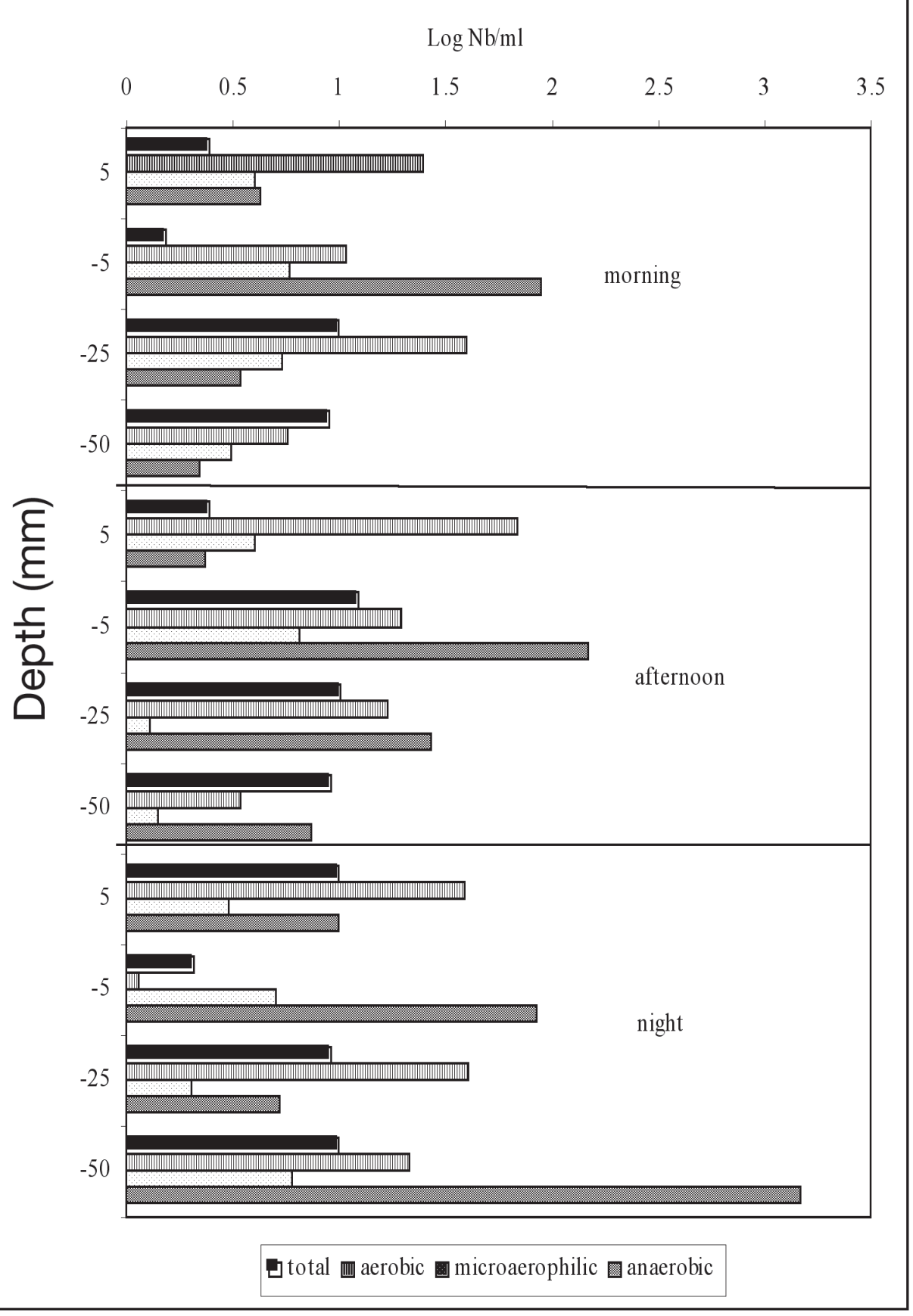

Fig. 6. Vertical variation of total bacterial density and different viable communities (aerobic, microaerophilic and anaerobic bacteria) in bottom water and $5 \mathrm{~mm}$ core sections into sediments, during morning, afternoon and night samplings.

Fig. 6. Variación vertical del número total de bacterias y de las diferentes comunidades viables (bacterias aeróbias, microaerofílica y anaeróbias) en el agua de fondo y en cada sección de $5 \mathrm{~mm}$ del núcleo, durante los muestreos de la mañana, tarde y noche. 
sediments underwent high variations along the day due to meteorological conditions, which brought about important exchanges between oceanic and lagoon water in summer (Dávila 1986, Llanos 1987, Ayala and Amaya 1995). According to the literature, the Coyuca de Benítez lagoon is classified as a mesotrophic water body in which the production processes prevail over the respiration process ones (Dávila 1986, Klimer 1988, Ramírez 1988, Monreal 1991).

This could explain the oxygen saturation values registered in the overlaying water and the sediment upper layer in the morning and afternoon samplings; this oxygen saturation could have favored the development of the heterotrophic aerobic bacteria, together with the fact that fine sediments are the preferred habitat of a great variety of pennades diatoms, which contribute to the sediments oxygenation by their photosynthetic activity (Admiraal et al. 1982, Baillie 1986), and to its enrichment in labile organic matter, which is prone to microbial degradation (Henrichs 1993).

The irregular profiles shown in the organic carbon distribution (Fig. 3) can be explained by the temporary sediment upper layer variation (first $5 \mathrm{~mm}$ depth), due to the direct influence of the wind, and to the local flow perturbation by protruding animal or sessile epifaunal organisms, that cause an irregular distribution of organic matter around their structures, such as it has been observed in these sediments (Roman 1991, Signoret and Brailovsky 2000). Benthic organisms react to such patchy distribution of food particles, as confirmed by Thomsen and Altenbach (1993) for shallowwater habitats.

The activity of both microphytobenthos and zoobenthos increase oxygen concentration in sediments. The phytobenthos does so through oxygen production, the zoobenthos through bioperturbation and irrigation, which facilitate the transport of oxidants into the deeper sediments, layer (Henrichs 1993) and stabilizes Eh in surface sediments. This would be explained too the irregular bacteria profiles found.
The regression multiple analysis, between the hydrological variables (Eh, \% organic carbon and porosity) at the three-moment of the day studied and the biological parameters variations, shown that the first are not predictors $\left(\mathrm{r}^{2}<0.5\right)$ of the bacterial populations distribution. Thus, the variations in the total number of heterotrophic bacteria observed in the two-day sampling, seem to be governed (with F-values of 0.6 to 0.9 ) by the irregular flows of bio-available organic material (lactate, mannitol, glucose) from the oceanic water and the Coyuca River, which enrich the lagoon by additional nutrients for the benthic bacterial populations and for the refractory detritus (floating plants, woods and reeds), that are issued from the mangrove vegetation and form the greatest part of the organic material in the lagoon (Delgadillo 1986).

The maximum biomass average values obtained in the first $5 \mathrm{~mm}$ of the sediment could be explained by its reduced state which favors the migration of dissolved reduced compounds from the deep sediment layers towards the upper layer, and then it was observed an important bacteria development with microaerophilic and anaerobic metabolisms. Meyer-Reil (1987), explained that these drastic daily changes of size and biomass in the benthic bacterial community are due to the assimilable organic material availability in the sediment surface.

Thus, the vertical distribution of the different viable bacterial populations with aerobic, microaerophilic and anaerobic respiratory metabolism seems also to be linked to a high excavating activity of the benthic resident meio- and macrofauna. This activity favors, on one hand, the formation of oxic microniches in the deep zones of the sediment due to the penetration of oxygenated water from the bottom towards the most reduced zones, which stimulate the growth of an aerobic and microaerophilic microflore in deep zones of the sediment. On the other hand, it favors the formation of reduced suboxic microniches in the sediment surface as a consequence of the diffusion of 
reduced compounds from the bottom toward the surface, and the dragging of the organic material of the sediment lower layers through galleries; this favors the development of aerobic-microaerophilic- anaerobic bacteria consortiums on the sediment oxygenated surface.

In the same way, the sediment particles resuspended by benthic organisms action or by wind and/or tide action turn into microhabitats showing strong and persistent $\mathrm{O}_{2}$ gradients. Nutrient transformations often rely microenvironmental or microzonal redox conditions. The spatial (microns to centimeters) and temporal (minutes to hours) requirements for microenvironmental overlap among microbial groups involved in nutrient transformations need close proximity and diffuse exchange with other biogeochemical distinct, yet complementary, microbial groups. These interactions, in short scales of time and space, control the microbial production, nutrients exchanges by releasing and exchanging biologically available forms of nutrients and metabolites and cycling within the ecosystem.

The microenvironments are colonized by $\mathrm{O}_{2}$-tolerant heterotrophic bacteria that consume the oxygen of the top and leave anaerobic zones where the bacterial microaerophilic $\left(\mathrm{N}_{2}\right.$-fixation) and anaerobic (C-fermentation) metabolisms can set up (Pearl and Pinckney 1996).

To sum up, it can be said that the vertical distribution of the bacterial biomass and the different respiratory groups studied in this system is strongly linked to the perturbation processes of the sediment by physical processes and by the activity of the autochthon benthic biota. Nevertheless, to understand the response of bacteria to benthic heterogeneity additional investigations should be taken into account together with bacterial activity (production and respiration).

\section{ACKNOWLEDGMENTS}

We thank the two anonymous reviewers of this article for their constructive criticisms, and Richard Peel for the linguistic correction of this manuscript; and Vanessa Morán-Villa and Roberto Angeles-Vázquez for the support in statistical analysis.

\section{RESUMEN}

Las fluctuaciones en el número, biomasa y composición de la comunidad bacteriana heterotrófica fueron estudiadas con respecto a la profundidad y a los cambios de profundidad, $\mathrm{pH}, \mathrm{Eh}, \mathrm{O}_{2}$ y concentración de carbono orgánico, durante un período corto de tiempo (diarias durante 2 días), en una zona del canal que comunica la laguna de Coyuca de Benítez (Guerrero, México) con las aguas costeras. Durante los tres momentos del día (6 am, 2 pm y 10 pm) estudiados, las concentraciones de oxígeno en el agua sobrenadante y en la película superficial del sedimento se encontraron próximas a la de saturación del aire durante los muestreos diurnos $(582 \mu \mathrm{M}$ a las 6 am y de $665 \mu \mathrm{M}$ a las $2 \mathrm{pm}$ ) y de subsaturación durante la noche $(158 \mu \mathrm{M})$. En los sedimentos, los modelos de distribución vertical del Eh y del carbono orgánico fueron muy irregulares debido a la bioperturbación causada por la meio- y macrofauna béntica, ya que su actividad excavadora permite que del carbono orgánico superficial pase a las capas más profundas del sedimento. La distribución vertical de la comunidad bacteriana heterotrófica viable parece estar ligada a la hidrodinámica del canal de comunicación y a la heterogeneidad de los sedimentos. En la columna de sedimento, el número total de bacterias heterótrofas variaron entre 6.8 y $20.3 \times 10^{8} \mathrm{cel} \mathrm{cm}^{-3}$. Los valores más altos de biomasa bacteriana heterótrofa se registraron en los muestreos realizados de día $\left(39.2 \mu \mathrm{gC} .1^{-1}\right.$ a las 6 am y 33.4 $\mu \mathrm{gC} .1^{-1}$ a las $\left.2 \mathrm{pm}\right)$ y los menores durante la noche $(9.7 \mu \mathrm{gC}$. $\left.1^{-1}\right)$. Las fluctuaciones del número de bacterias viables con diferentes metabolismos respiratorio (aeróbicos, microaerofílicos y anaeróbicos), se pueden explicar por la existencia de micronichos subóxicos que se forman debido a la resuspensión de partículas sedimentarias por la circulación del agua y por acción de las actividades de excavación de los organismos bentónicos que a través de sus galerías permiten que el oxígeno del agua sobrenadante penetre a las zonas más profundas del sedimento. El análisis estadístico (Modelo de regresión lineal múltiple $\mathrm{r}^{2} \geq 0.5$ ) señaló que no hubo una relación directa entre los parámetros hidrológicos y la abundancia de las poblaciones bacterianas $\left(\mathrm{r}^{2} \leq 0.5\right)$. Sin embargo, las variaciones de la comunidad bacteriana heterotrófica observada durante los dos días de muestreo, pareció estar gobernada por los flujos irregulares de materia orgánica biodisponible y por la porosidad del sedimento (F-valores de 0.6 a 0.9 )

Palabras clave: laguna costera, oxígeno, sedimentos, bacterias heterotróficas, aerobias, microaerofílicas, anaerobias. 


\section{REFERENCES}

Admiraal, W., H. Peletier \& H. Zomer. 1982. Observations and experiments on the population dynamics of epipelic diatoms from an estuarine mudflat. Estuarine, Coastal and Shelf Sci. 14: 471-487.

Albright, L.J., S.K. McCrae \& B.E. May. 1986. Attached and free-floating bacterioplankton in Howe Sound British Columbia, a coastal marine Fjord-Embayment. Appl. Envir. Microbiol. 51: 614-621.

Alldredge, A.L. \& Y. Cohen. 1987. Can microscale chemical patches persist in the sea? Microelectrode study of marine snow, fecal pellets. Science 235: 689-691.

Ayala, F. \& A.M. Amaya. 1995. Evaluación preliminar de tres lagunas costeras en el estado de Guerrero, México. (Chautengo, Tres Palos y Coyuca), para determinar su potencial camaronícola. In Res. XIII Congr. Nal. de Zool. Mexico, Mexico. 135 p.

Azam, F., T. Fenchel, J.G. Field, J.S. Gray, L.A. MeyerReil \& F. Thingstad. 1983. The ecological role of water-column microbes in the sea. Mar. Ecol. Prog. Ser. 10: 257-263.

Baillie, P.W. 1986. Oxygenation of intertidal estuarine sediments by benthic microalgal photosynthesis. Estuarine, Coastal and Shelf Sci. 22:143-159.

Boyd, C.E. 1995. Bottom soils, sediment, and pond aquaculture. Chapman \& Hall, London, England. 368 p.

Bratbak, G. 1985. Bacterial biovolume and biomass estimation. Appl. Environ. Microbiol. 49:1488-1493.

Cammen, L.M. 1991. Annual bacterial production in relation to benthic microalgal production and sediment oxygen uptake in an intertidal sandflat and intertidal mudflat. Marine Ecol. Progr. Ser. 71:13-25.

Caron, D.A., J.C. Goldman \& M.R. Dennett. 1986. Effect of temperature on growth, respiration and nutrient regeneration by an omnivorous microflagellate. Appl. Environ. Microbiol. 52: 1340-1347.

Cho, B.C. \& F. Azam. 1990. Biogeochemical significance of bacterial biomass in the ocean's eutrophic zone. Mar. Ecol. Prog. Ser. 63: 253-259.

Contreras, F. 1985. Ecosistemas costeros mexicanos. UAM, Iztapalapa, Mexico. 415 p.

Daumas, R. 1989. Les bactéries de la couche superficielle du sédiment, p. 201-218. In M. Bianchi, D. Marty, J-C. Bertrand, P. Caumette \& M. Gauthier (eds.). Microorganismes dans les écosystèmes océaniques. Masson, Paris, France.
Dávila, Z.J.J. 1986. Distribución y abundancia del fitoplancton durante el ciclo estacional verano 83-verano 84 en la laguna de Coyuca de Benitez, Guerrero. Tesis de Licenciatura, Universidad Autónoma de México, Mexico D.F., Mexico. 135 p.

Delgadillo, E.A. 1986. Evaluación de la materia orgánica particulada en la laguna de Coyuca de Benítez, Gro. durante el ciclo otoño 1983-verano 1984 y su relación con Percepción remota. Tesis de Licenciatura. Universidad Autónoma Metropolitana, Mexico D.F., Mexico. 82 p.

Ferrara-Guerrero, M.J. \& A. Bianchi. 1989. Comparison of culture methods for enumeration of microaerophilic bacteria in marine sediments. Res. Microbiol. Inst. Pasteur/Elsevier 140: 225-261.

Ferrara-Guerrero, M.J. \& A. Bianchi. 1990. Distribution of microaerophilic bacteria through the oxic-anoxic transition zone of lagoon sediments. Hydrobiologia 207: $147-152$.

Ferrara-Guerrero, M.J., D. Marty \& A. Bianchi. 1993. Isolation and enumeration of anaerobic and microaerophilic bacteria in aquatic habitats, p. 9-19. In P.F. Kemp, B.F. Sherr, E.B. Sherr \& J.J. Cole (eds.). Current methods in aquatic microbial ecology. Lewis, Florida, USA.

Fuhrman, J.A., T.D. Sleeter, C.A. Carlson \& L.M. Proctor. 1989. Dominance of bacterial biomass in the Sargrasso Sea and its ecological implications. Mar. Ecol. Prog. Ser. 57: 207-217.

Gallardo, J.F., J. Saavedra \& T. Martín-Palino. 1987. Solid organic matter determination. Comm. Soils Sci. Plants Ann. 18: 699-707.

Henrichs, S.M. 1993. Early diagenesis of organic matter: the dynamics (rates) of cycling of organics compounds, p. 101-118. In M.H. Engel \& S.A. Macko (eds). Organic geochemistry, principles and applications. Plenum, New York, USA.

Hicks, G.R.F. 1992. Tidal and diel fluctuations in abundance of meiobenthic copepods on an intertidal estuarine sandbank. Mar. Ecol. Prog. Ser. 87: 15-21.

Hobbie, J.E., R.J. Daley \& S. Jasper. 1977. Use of Nuclepore filters for counting bacteria by fluorescence microscopy. Appl. Envir. Microbiol. 33: $1225-1228$

Holligan, P.M., R.P. Harris, R.C. Newell, D.S. Harbour, R.N. Head, E.A.S. Linley, M.I. Lucas, P.R.G. Tranter \& C.M. Weekly. 1984. Vertical distribution and partitioning of organic carbon in mixed, frontal and stratified waters of the English Channel. Mar. Ecol. Prog. Ser. 14: 111-127. 
Hungate, R.E. 1969. A roll tube method for cultivation of strict anaerobes, p. 117-132. In J.R. Norris \& D.W. Ribbon (eds.). Methods in microbiology. Academic, London, England.

Jørgensen, B.B. \& N.P. Revsbech. 1985. Diffusive boundary layer and the oxygen uptake of sediments and detritus. Limnol. Oceanogr. 30: 111-122.

Klimer, R. 1988. The hydrochemistry, productivity and sea water interaction of three coastal tropical lagoons in the south of Mexico. Res. Joint Oceanography Assembly. $53 \mathrm{p}$.

Llanos, J.R. 1987. Abundancia y distribución del zooplancton en la laguna de Coyuca de Benitez, Guerrero, México. Tesis de Licenciatura, Universidad Autónoma de México, D.F. Mexico, Mexico. 115 p.

Maksymowska-Brossard, D. \& H. Piekarek-Jankowska 2001. Seasonal variability of benthic ammonium release in the surface sediments of the Gulf of Gdańsk (southern Baltic Sea). Oceanologia 43: 113-136.

Marrasé, C., E.L. Lim \& D.A. Caron. 1992. Seasonal and daily changes in bacterivore in a coastal plankton community. Mar. Ecol. Prog. Ser. 82: 281-289.

Marty, D., J.-C. Bertrand \& P. Caumette. 1989. Les métabolismes bactériens dans les systèmes sédimentaires marins, p. 101-151. In M. Bianchi, D. Marty, J-C. Bertrand, P. Caumette \& M. Gauthier (eds.). Microorganismes dans les écosystèmes océaniques. Masson, Paris, France.

Meyer-Reil, L.A. 1987. Seasonal and spatial distribution of extracellular enzymatic activities and microbial incorporation of dissolved organic substrates in marine sediments. Appl. Envir. Microbiol. 53: $1748-1755$.

Monreal, P.A. 1991. Evaluación de la concentración de la clorofila $a$ fitoplanctónica estacional en la laguna de Coyuca de Benítez, Guerrero, utilizando técnicas hidrobiológicas y de percepción remota. Tesis de licenciatura, Universidad Autónoma de México, Mexico D.F., Mexico. 175 p.

Morris, J.G. 1984. Changes in oxygen tension and microbial metabolism of organic carbon, p. 59-96. In G.A Codd (ed.). Aspects of microbial metabolism and ecology. Society for General Microbiology. Academic, London, England.

Oppenheimer, C.H. \& C.E. ZoBell. 1952. The growth and viability of sixty-tree species of marine bacteria as influence by hydrostatic pressure. J. Mar. Res. 11: $10-18$
Pearl, H.W. \& J.L. Pinckney. 1996. A mini-review of microbial consortia: their role in aquatic production and biogeochemical cycling. Microb. Ecol. 31: 225-247.

Pomeroy, L.R., W.J. Wiebe, D. Deibel, R.J. Thompson, G.T. Rowe \& J.D. Pakulski. 1991. Bacterial responses to temperature and substrate concentration during the Newfoundland spring bloom. Mar. Ecol. Prog. Ser. 75: 143-159.

Porter, K.G. \& Y.S. Feig. 1980. The use of DAPI for identifying and counting aquatic microflora. Limnol. Oceanogr. 25: 943-948.

Ramírez, R. 1988. Laguna de Coyuca de Benitez, Guerrero, un sistema de estudio integrado. Tesis de Licenciatura. Universidad Autónoma de México, Mexico D.F., Mexico. 64 p.

Rasmussen, H. \& B.B. Jǿrgensen. 1992. Microelectrode study of seasonal oxygen uptake in a coastal sediments: role of molecular diffusion. Mar. Ecol. Progr. Ser. 81: 289-303

Revsbech, N.P., J. Sǿrensen, T.H. Blackburn \& J.P. Lomholt. 1980. Distribution of oxygen in marine sediments measured with microelectrodes. Limnol. Oceanogr. 25: 403-408.

Roden, E.E. \& J.H. Tuttle. 1992. Sulfide release from estuarine sediments underlying anoxic bottom water. Limnol. Oceanogr. 37:725-738.

Roman, C.R. 1991. Ecología de Macrobrachium tenellum (Decapoda: Palemonidae) en la laguna Coyuca, Guerrero, Pacífico de México. An. Inst. Cienc. del Mar y Limnol. UNAM. 18: 109-121.

Sanders, R.W., D.A. Caron \& U.G. Berninger. 1992. Relationships between bacteria and heterotrophic nanoplankton in marine and fresh waters: an inter-ecosystem comparison. Mar. Ecol. Prog. Ser. 86: 1-14.

Sherr, E. \& B. Sherr. 2000. Marine microbes. An Overview, p. 13-46. In D.L. Kirchmen (ed.). Microbial ecology of the oceans. Wiley, New York, USA.

Signoret, G. \& D. Brailovsky. 2000. Population study of Macrobachium tenellum (Smith) in the lagoon of Coyuca de Benítez, Gro., Mexico. In The Crustacean Society 2000 Summer Meeting. Puerto Vallarta, Mexico.

Thomsen, L. \& A.V. Altenbach. 1993. Vertical and area distribution of foraminiferal abundance and biomass in microhabitats around inhabited tubes of marine echiurids. Mar. Micropaleontol. 20: 303-309. 
Torréton, J-P. 1991. Importance des bactéries hétérotrophes aérobies dans une lagune eutrophe tropicale (Lagune Ebrié, Côte d'Ivoire). Doctorate thesis, Université d'Aix-Marseille II, France. 246 p.

Van Wambeke, F. 1988. Numération et taille des bactéries planctoniques au moyen de l'analyse d'images couplée à l'épifluorescence. Ann. Inst. Pasteur/ Microbiology 139: 261-272.
Watson, S.W., T.J. Novitsky, H.L. Quinby \& F.W. Valois. 1977. Determination of bacterial number and biomass in the marine environment. Appl. Envir. Microbiol. 33: $940-946$.

Wikner, J., F. Rassoulzadegan \& Å. Hagtröm. 1990. Periodic bacterivore activity balances bacterial growth in the marine environment. Limnol. Oceanogr. 35: 313-324. 
